hope of success could be entertained and the site was abandoned as another dry hole after $260 \mathrm{ft}$. had been added to that depth.

Both these reports are admirably produced, and apart from including maps, plans, structural data and detailed well-logs, the geophysical, palæontological and petrologica] details obtained from the well-samples recovered are fully documented. Notwithstanding that both these Queensland projects merely add to the discouragingly long list of failures to find commercial oilpools in Australia, at least one success has to be recorded. With the start of a pipeline from the Moonie field to Brisbane, what is described as ". . . the beginning of the end of a long and arduous undertaking to produce Australia's first commercial oilfield" has undoubtedly given a fillip to oil exploration at least in this part of the Continent. According to The Australian Mineral Industry (16, No. 1, September 1963), the Moonie pipeline is to be equipped with one pumping station on the oilfield and it will initially be capable of delivering up to 10000 barrels of crude oil per day. Should future developments and discoveries warrant it, the capacity of the line can be boosted to 57000 barrels per day; this would necessitate erection of three more pumping stations. There is definitely some hope in the Moonie area because one woll, Moonie No. 17, produced oil at the rate of 1,891 barrels per day through a $\frac{1}{2}$-in. choke during a production test on two zones, an upper and a lower; it is the second of 15 successful wells in this field to produce from these zones. A gas production rate of $213,000 \mathrm{ft}^{3}$ per day, also proved. lends further encouragement to continue the search.

H. B. Mulner

\title{
DOMESTIC FOOD CONSUMPTION AND EXPENDITURE IN BRITAIN, 1961
}

$\mathrm{T}$ HE pattern of food supplies in 1961 was broadly similar to that in 1960 , but some trends in the level of supply of individual commodities continued. Thus supplies of milk, cream, cheese and eggs moving into consumption again increased while those of fish and flour continued to decline. Total supplies of meat rose to $128 \mathrm{lb}$. (edible weight) per head. The total level of supply of butter was almost as great as in 1958 and resulted in a curtailment of demand for margarine. Supplies of potatoes were slightly greater than in the previous year, but those of most fresh fruits and vegetables declined. These facts are given in the annual report of the National Food Survey Committee entitled Domestic Frood Consumption and Expenditure, $1961 *$.

The Report is the twelfth of an annual series introduced in 1950 relating to consumption, expenditure and nutrition of private households in Great Britain. Evidence is also presented that, between 1956 and 1961, differences associated with social class and household composition have narrowed. Food expenditure increased at slightly higher

* Ministry of Agriculture, Fisheries and Food. Domestic Food Consumption and Expenditure, 1961-Annual Report of the National Food Survey Committee. Pp. vili +124. (London: H.M.S.O., 1963.) 8s. 6d. net. rates in the lower income groups (including pensioner households) and in large families.

In one of the two special investigations, the report shows that the average numbers of earners and the average net income per household together with the food expenditure per person were slightly lower in families including an expectant mother than in those without. Also the differences in type of diet between larger and smaller households were accentuated when the housewife was pregnant. The other special investigation examines the impact on the demand for carcass meat of the expansion of the poultry industry between 1956 and 1961. This shows that since 1959 the consumption of carcass meat has not decreased in spite of increased consumption of poultry.

Apart from tables containing extensive data relating to consumption, nutrition and expenditure, the appendixes include an account of the methods used in conducting the survey and analysing the results. Although the National Food Survey is primarily intended to provide information for the Government, its findings should be of interest to all who are interested in nutritional and dietary matter's and production of food for the home market. D. Pearson

\section{TOOTH REPLACEMENT IN THE MAMMAL-LIKE REPTILES}

$\mathrm{I}_{\mathrm{o}}^{\mathrm{N}}$ any attempt to derive the mammals from the reptiles, one of the problems encountered in the past has been the virtual impossibility of reconciling the apparently different methods of tooth replacement found in these two classes. Thus Dr. A. W. Crompton's recent analysis of the situation in some of the most mammalian of the mammallike reptiles, the cynodonts, is of considerable interest, for he demonstrates that within this small group both types of dentition are represented*.

From a more complete series of developmental stages than has hitherto been known, Dr. Crompton confirms in Thrinaxodon Parrington's contention that the teeth are replaced alternately, and he shows further that the wave of replacement passes from back to front along both the odd and even teeth, exactly as in typical reptiles. This is despite the mammalian appearance of the teeth themselves. In the gomphodont cynodonts, on the other hand, Crompton observes that in contrast to the situation in Thrinaxodon, the replacement is from front to back, while there is no sign of an alternate succession. This latter dentition therefore parallels that seen in the mammals.

- Annals of the South African Museum, 46, Part 20: Tooth Replacement in the Cynodont Thrinaxodon liorhinus Seeley. By A. W. Crompton. Pp. 479521. (Cape Town: South African Museum, 1963.) 75 cents.
Crompton's observations thus help to confirm the theory recently postulated by Edmund on tooth replacement patterns (Contrib. Roy. Ontario Mus., Life Sci. Div., 52, 1; 1960). He suggests that impulses travel along the dental lamina initiating the development of successive tooth germs, and where consecutive impulses are spaced at a distance of twice that between tooth germs, then a fully alternate dentition results. If, however, there is slightly more than this distanee between impulses, there is a time lag before the more anterior teeth appear, so that the wave of replacement of both odd and even teeth will appear to be from back to front of the jaw. If the interval is less than twice this distance, then the wave will appear to travel in the reverse direction.

Edmund further believes that each animal possesses more than one generation of teeth, or Zahnreihe, and, again using Edmund's theory, Crompton shows that in Thrinaxodon there is an endless succession of Zahnreihen, while in the gomphodont cynodonts there are only two, part of the second being suppressed. It is this reduction of Zahnreihen which accounts for the lack of an alternate succession in the gomphodont cynodonts, as it does in the mammals where part of the second Zahnreihe is also sup. 
pressed. Clearly, therefore, Dr. Crompton's work is of some considerable significance since, by his analysis of two apparently opposed dentitions within one small group of mammal-like reptiles, he is able to support strongly the view put forward by Edmund, that the method of tooth replacement in the mammals can be derived quite simply from that known in normal reptiles. Thus the supposed fundamental difference between the reptiles and the mammals in this respect can now be seen to be more apparent than real.
L. B. H. Tarlo

\title{
FORMATION OF SEDIMENTARY BASINS BY DUCTILE FLOW OF ISOSTATIC ORIGIN IN THE UPPER MANTLE
}

\author{
By Dr. M. H. P. BOTT \\ Department of Geology, University of Durham
}

\begin{abstract}
T the middle of the nineteenth century, James Hall ${ }^{1}$ observed that an aggregate thickness of $40,000 \mathrm{ft}$. of Palæozoic rocks mostly bearing evidence of shallow water origin were deposited in the Appalachian region (later to be named the Appalachian geosynclinal by Dana ${ }^{2}$ ). He inferred consequently that sedimentation kept close pace with a gradual or periodic subsidence.
\end{abstract}

A similar problem is posed by sediments of Carboniferous age deposited in central and north Great Britain, although these were formed in intra-cratonic basins and troughs rather than in an orthogeosyneline. Lower Carboniferous sediments vary considerably in thickness, and in certain regions such as the Midland Valley of Scotland ${ }^{3}$ and the Mid-Northumberland Trough ${ }^{4-6}$ they reach thicknesses of the order of $6-8,000 \mathrm{ft}$.; sedimentary indications ${ }^{7}$ such as coal seams and rootlet beds in association with shallow water marine limestones show that deposition took place not far from sea-level throughout. Similar thicknesses and variations in thickness are also known for the Upper Carboniferous rocks ${ }^{8}$; for example, the Millstone Grit attains thicknesses of 4-7,000 ft. in the Central Pennines and the Coal Measures attain 8,000 ft. in the Lancashire coal basin; the presence of occasional marine bands in association with fresh- to brackish-water deposits with coal seams and rootlet beds shows that deposition took place close to but generally slightly above sea-level. Thus the direct inference can be made that major differential subsidence was taking place at approximately the same rate as sedimentation throughout. In the Lower Carboniferous, some of the differential subsidence is known to have occurred along relatively narrow belts bounded by hinge lines, one of these forming the southern boundary of the Mid-Northumberland Trough ${ }^{4-6}$. A further interesting feature of Carboniferous sedimentation in Britain is the pattern of cyclothemic (rhythmic) sedimentation seen when the average level of deposition is close to or slightly above sea-level; in the Lower Carboniferous the Yoredale facies consists ideally of a repeated sequence of limestone, shale, sandstone and coal, and in Coal Measures the generalized sequence is marine band, shale, sandstone and coal seam. Each unit, or cyclothem, is about $100 \mathrm{ft}$. thick. The simplest direct explanation of these repetitions is periodic rapid subsidence of about $100 \mathrm{ft}$. with intervening periods of relative quiescence ${ }^{2}$, although explanations involving continuous subsidence have also been suggested. Westoll ${ }^{10}$ gives a summary of hypotheses.

A source for British Carboniferous sediments requires a mountain region considerably more substantial in volume than present high ground in Britain. The early appearance of dominantly non-marine sediments in the north and indications coming from current bedding and channels conspire to suggest that the main source of the sediments lies to the north. It is tempting to equate this source with the Caledonian mountain range which crossed north Scotland with a north-east strike. To complete the palæogeographic setting ${ }^{3}$, the Hercynian geosyncline oovered part of south England and the incipient Amorican mountain chain lay even farther to the south.
Hall ${ }^{1}$ explained the close balance between sedimentation and subsidence in the Appalachian region by attributing the subsidence to the weight of the accumulating sediments. This mechanism, however, has been shown (for example, Jeffreys ${ }^{11}$ ) to be inadequate on classical ideas of isostasy, since the load of sediments completely filling a sea can only cause sinking slightly greater than the original depth of the sea, which is demonstrably shallow; further sinking can thon only occur if sodiments are piled up progressively above sea-level. Dana ${ }^{2}$ explained both the sinking of the Appalachian geosyncline and the subsequent mountain building movements as caused by lateral compression due to a contracting Earth; but this explanation is clearly inadequate to account for the epeirogonic Carboniferous intra-cratonic basins of Britain. Barrell ${ }^{12}$ later gave an explanation for the disposal of sediments in excess of the volume needed to fill a subsiding basin by suggesting the excess sediment cannot be deposited above the local 'base-level' of deposition and is therefore carried to more distant regions; this, however. does not give a mechanism for the subsidence and can only account for the disposal of sediment in excess of the requirements for filling the basin.

Thus there is a major outstanding problem over the mechanism of subsidence of sedimentary basins and geosynclines other than those of primary origin. Two associated problems concern the close balance between subsidence and sedimentation and the cause of rhythmic sedimentation. These problems are discussed here primarily in relation to the British Carboniferous basins, since the contemporaneous subsidence and balance between subsidence and sedimentation can be demonstrated. But it is considered that the hypothesis advanced is also relevant to other sedimentary basins and some goosynclines, notably the Old Red Sandstone and Permo-Triassic basins of Britain and the Lower Palæozoic eugeosyncline of Britain.

Subsidence of the magnitude involved in geosynelines and large sedimentary basins undoubtedly affects both the crust and the uppermost mantle. If the Earth's volume is to remain constant it is logical to postulate that downwarping and subsidence must usually be accompanied by complomentary upwarps of approximatoly similar volume and that these complementary movements are linked by a lateral flow at some depth beneath, presumably within the upper mantle. (Exceptions to the postulate include subsidence due to outpouring of igneous rocks at the surface and possible changes in the Earth's volume due to phase changos in the upper mantle, etc.) Complementary subsidence and uplift has been recognized for yoked sedimentary basins (zeugogeosynclines ${ }^{13}$ ) such as the Denver basin of Pennsylvanian and Permian age linked to the rise of the ancestral Rocky Mountains and for the exogeosynclines and epieugeosynclines of Kay ${ }^{13}$; it has also been recognized for orthogeosynclines in the concept of the geanticline. It has not, howevor, been so widely recognized for sedimentary basins such as the Carboniforous and Permo-Triassic intra-cratonic basins of Great 